\title{
Virtual screening and in silico design of novel inhibitors of bacterial lectins
}

\author{
Jan Alán ${ }^{1,2^{*}}$, Petr Kulhánek ${ }^{1,2}$, Jaroslav Koča ${ }^{1,2}$ \\ From 7th German Conference on Chemoinformatics: 25 CIC-Workshop \\ Goslar, Germany. 6-8 November 2011
}

Bacterium Pseudomonas aeruginosa is a human opportunistic pathogen. It can cause infection of immunocompromised people or people suffering from cystic fibrosis, which is often fatal. Bacterial colonization of human tissues is mediated by interaction of bacterial surface proteins - lectins - with cellular surface carbohydrates. PA-IIL is Pseudomonas aeruginosa tetrameric lectin, which contains two calcium ions in each binding site and recognizes fucosylated oligosaccharides [1]. Saturation of bacterial surface lectins by specially designed compounds might prevent adhesion to host tissues and thus suppress the infection. In this work, virtual screening and docking were used for identification of compounds that might inhibit this interaction and be potentially used as a new generation of antibiotics.

Two different approaches for identification of promising compounds were employed. Subset of drug-like molecules was docked into the PA-IIL binding site by Autodock Vina [2] and Dock 6 [3]. Interesting ligands were then selected by identifying those with highest score provided by both programs. In the second approach, we focused on the identification of interesting molecular fragments, which should be attached to already pre-docked carbohydrate. The carbohydrate serves as a targeting agent and newly identified fragments increase its interaction with the lectin. In both approaches, ZINC library [4] was the source of ligands and fragments.

\section{Acknowledgements}

The work is supported by the Ministry of Education (MSM0021622413, LC6030, ME08008), the Czech Science Foundation (GA/303/09/1168, GD301/ 09/H004) of the Czech Republic, the European Community's Seventh Framework Programme (grant agreement $n^{\circ}$ 205872) and the project

\footnotetext{
*Correspondence: alan@chemi.muni.cz

${ }^{1}$ CEITEC - Central European Institute of Technology, Masaryk University, Kamenice 5, 62500 Brno, Czech Republic

Full list of author information is available at the end of the article
}

"CEITEC - Central European Institute of Technology" (CZ.1.05/1.1.00/02.0068) from European Regional Development Fund.

\section{Author details}

${ }^{1}$ CEITEC - Central European Institute of Technology, Masaryk University, Kamenice 5, 62500 Brno, Czech Republic. ${ }^{2}$ National Centre for Biomolecular Research, Faculty of Science, Masaryk University, Kotláská 2, 61137 Brno, Czech Republic.

Published: 1 May 2012

\section{References}

1. Adam J, et al: Engineering of PA-IIL lectin from Pseudomonas aeruginosa - Unravelling the role of the specificity loop for sugar preference. $B M C$ Struct Biol 2007, 7:36.

2. Trott $\mathrm{O}$, et al: AutoDock Vina: improving the speed and accuracy of docking with a new scoring function, efficient optimization, and multithreading. J Comput Chem 2010, 31:455-461.

3. Kuntz ID, et al: A geometric approach to macromolecule-ligand interactions. J Mol Biol 1982, 161:269-288.

4. Irwin JJ, et al: ZINC-a free database of commercially available compounds for virtual screening. J Chem Inf Model 2005, 45:177-182.

\section{doi:10.1186/1758-2946-4-S1-P1}

Cite this article as: Alán et al:: Virtual screening and in silico design of novel inhibitors of bacterial lectins. Journal of Cheminformatics 20124 (Suppl 1):P1.

\section{Publish with ChemistryCentral and every scientist can read your work free of charge \\ "Open access provides opportunities to our colleagues in other parts of the globe, by allowing anyone to view the content free of charge." \\ W. Jeffery Hurst, The Hershey Company. \\ - available free of charge to the entire scientific community \\ - peer reviewed and published immediately upon acceptance \\ - cited in PubMed and archived on PubMed Central \\ - yours - you keep the copyright \\ Submit your manuscript here: \\ http://www.chemistrycentral.com/manuscript/

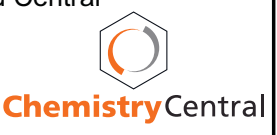

C 2012 Alán et al; licensee BioMed Central Ltd. This is an Open Access article distributed under the terms of the Creative Commons Attribution License (http://creativecommons.org/licenses/by/2.0), which permits unrestricted use, distribution, and reproduction in any medium, provided the original work is properly cited. 